\title{
Dissenting from Edward Young's Night Thoughts: Christian Time and Poetic Metre in Anne Steele's Graveyard Poems
}

\author{
KATARINA STENKE
}

\begin{abstract}
Although the Particular Baptist poet Anne Steele (I7I8-I778) is little known today, this article argues that her poems on time and death offer valuable insights into wider religio-poetical representations of time in the mid-eighteenth century. Her verse both responds to and departs from the conventions of graveyard poetry as exemplified by Edward Young's Night Thoughts (I742-6), demonstrating close engagement with this popular subgenre as well as an intelligent critique of its devotional poetics. As such, Steele's writing foregrounds yet also problematises emerging distinctions between writing and religion, and thus argues for new methodologies in religious and literary history.
\end{abstract}

Keywords: Edward Young, Anne Steele, graveyard poetry, gender, history of time, history of religion, history of poetry and poetics, eighteenth-century nonconformity

\author{
Little Monitor, by thee \\ Let me learn what I should be; \\ Learn the round of life to fill, \\ Useful and progressive still. \\ Thou canst gentle hints impart \\ How to regulate the heart: \\ When I wind thee up at night, \\ Mark each fault, and set thee right: \\ Let me search my bosom too, \\ And my daily thoughts review; \\ Mark the movement of my mind, \\ Nor be easy when I find \\ Latent errors rise to view, \\ Till all be regular and true. ${ }^{\text {I }}$
}

These lines first appeared in print under the title 'To My Watch' in the I780 three-volume edition of Poems on Subjects Chiefly Devotional, a collection of hymns, poems and prose meditations by the Particular Baptist author Anne Steele (I7I8-I778). Despite its brevity, the poem offers a telling introduction to the temporal themes and conceits of Steele's verse and encapsulates many of the features that make her publications such revealing case studies of devotional and - as in this instance - moral-didactic poetry. Steele's poems about time are worth reading today for several reasons. They display the range and sophistication of a poet known to modern audiences, if at all, as a hymnist. They reveal Steele's engagement in the textual cultures of her day, the models on which she formed her print persona and the rather different self-image visible in the manuscript verse she shared with family and friends. They also encapsulate a mode of writing about time in 
the eighteenth century that literary scholars are only just beginning to rediscover, one that is religious insofar as it derives from Christian doctrine and practice, and poetic in its reliance on metre, rhyme and figurative language. What follows, therefore, takes a deliberately literary-critical approach to an author who has hitherto been studied mainly in the context of religious culture. It thereby seeks not to undermine but rather to build on existing accounts of her life and work that situate her within the history of English nonconformity or that consider her primarily as a hymnist. Steele's faith and religious community are crucial to her work, undoubtedly. However, the medium in which she wrote needs to come into sharper focus if we are to reach a true, historically calibrated understanding of it, as becomes clear when we look carefully at 'To My Watch'.

Endearingly or trivially 'little', the watch is, first of all, amusingly personified - one sense of 'Monitor' being 'a person who gives advice or warning as to conduct'. ${ }^{2}$ Even understood more soberly, as an object fulfilling the same function, it is a pleasingly compact didactic emblem which encompasses a series of witty contrasts and equivalences. The 'round of life' evokes at once the round of the clock-face and the diurnal cycles it represents, which will eventually accumulate to the span of a human life. The speaker, then, hopes to learn how to fill that daily round so that it will become consistently 'useful and progressive' - with 'still' here hinting at the alternative to progress, the stasis of the stopped clock or the empty, useless life. At line 7 the conceit develops with a reversal of monitor and monitored, which in turn prompts a plea for self-monitoring. Thus the speaker's evening routine of 'monitoring' the watch, ensuring it keeps time by checking it for faults and adjusting it, is proposed as an ideal occasion for doing the same to her own faculties: to 'search my bosom', 'mark each movement of my mind' and repair the 'latent errors [that] rise to view'.

Self-regulation is therefore at the heart of the poem's message, and the 'how to regulate' of line 6 is echoed in the last line as 'till all be regular'. The poem's rhythms underscore this shift from a pattern or blueprint for regulation to a representation of the anticipated, future result of such practice. Steele here uses a 'little' or cropped variety of the tetrameter couplets she often favoured, the trochaic tetrameter catalectic, in which each line starts and ends on a stressed syllable. This produces a preponderance of stresses and a marked break between lines, evoking the mechanical movements of the watch or the way its clockwork begins to slow as it winds down towards the end of each day. It is only in the final line, looking to future achievement - 'Till all be regular and true' - that iambic regularity and rapidity are established with a 'filled' tetrameter of eight syllables.

The poem plays with time in a variety of ways, then, and the 'watched' or regulated life is keyed to the regulated line as well as to the regulated, regulating timepiece. In contrast to much of Steele's work, content of an explicitly Christian kind is absent here. Nonetheless, the parallel between day and life suggests the conventional analogy between night and death prominent in devotional literature of the period and deploys what I shall propose is a set of standard topoi relating to time and death that self-consciously bind the rhythms of poetry to the temporalities of Christianity. To notice these kinds of formal and figurative detail, therefore, allows us to challenge existing, predominantly secularist, models for how eighteenth-century literature represents time, such as that outlined by

Stuart Sherman in his influential monograph Telling Time: Clocks, Diaries and English Diurnal Form I660-I785 (I996). It can also help to redraw the traditional distinctions between, and approaches to, religious and literary history.

Sherman argues that the seventeenth and eighteenth centuries saw the development of increasingly sophisticated and finely graduated 'modes of temporal notation' attendant on 
contemporary advances both in chronometry, in the form of newly accurate and portable timepieces, and in print circulation, with the proliferation of daily newspapers and journals. ${ }^{3}$ This consciousness, in turn, Sherman claims, informs 'self-construction' in non-fiction genres such as autobiography and diaries in ways that calibrate the time of private individuals to that of the public sphere. ${ }^{4}$ Steele's poetical address to her watch certainly seems to lend itself to Sherman's arguments insofar as it testifies to the vivid sense of time and self afforded by privately owned watches. The very occasion of the poem results from a feature of contemporary chronometry, the fact that mainspring clockwork needed to be wound up, adjusted and set going again on a regular basis. This limitation is mapped onto the poet's heart and mind in a metaphor that not only attributes to the self a propensity to irregularity, equating mechanical accuracy and moral virtue but also gives that tendency a specifically temporal character. ${ }^{5}$ Unless they are 'set right' each day, like a watch, human beings will incline to wrong. ${ }^{6}$

Sherman understands eighteenth-century British literature as a largely secular domain. In this he develops a secularisation narrative that has informed histories of time since at least the mid-twentieth century, but he makes little mention of the important place accorded to religion in such earlier scholarship. In a well-known essay from I960 on 'church time and merchant time' in the Middle Ages, for instance, the French historian Jacques Le Goff describes a shift in the perception and control of time whereby the work patterns of secular professions increasingly encroached on the religious calendars instituted by the Church. Rather than being entirely obliterated, however, such routines were instead incorporated within a mercantile temporality. ${ }^{7}$ A religious component is visible too in E. P. Thompson's seminal account of how 'the apprehension of time' in English culture developed in tandem with technological advances and changes to labour patterns during the eighteenth century and into the nineteenth. ${ }^{8}$ For Thompson, modern 'work-discipline' and clock time are not entirely new phenomena resulting from industrialisation and technological advances but rather reinvigorate and reorient the programme of careful temporal husbandry recommended by Puritan and evangelical authors from Richard Baxter to Hannah More. ${ }^{9}$ As in Le Goff's argument, then, Thompson's essay describes how a temporality adapted to economic ends assimilates and draws advantage from a sense of time based on Christian belief and practice.

More recent scholarship in the field of literature likewise reminds us that there were other representations of time available in this period than those identified by Sherman. In Prose Immortality (2015) Jacob Sider Jost identifies a strong correlation between eighteenth-century literary representations of Christian immortality and the contemporary development of new ways of thinking about and producing literary posterity. Sider Jost argues convincingly that the most influential periodical of the eighteenth century, The Spectator, does not represent a secular reinvention of the Biblical fullness of time, as Sherman claims. ${ }^{\mathrm{IO}}$ Rather, the journal's 'formal innovations [...] are interventions in the theological world of late Stuart and Hanoverian Britain', designed to model the relationship between the virtuous 'filling' of small units of time and the Christian immortality such virtuous plenitude promises. ${ }^{\text {II }}$ These insights are eminently applicable to the writings of Anne Steele, suggesting, as they do, ways of reworking Sherman's thesis to take into account the continuing importance of religious belief to mainstream eighteenthcentury literary culture. If the canonical works discussed by Sider Jost represent time in Christian terms and to devotional ends, it becomes much easier to see why and how a "chiefly devotional' author such as Steele might draw on them. Furthermore, of the examples adduced in Prose Immortality, the hugely popular The Complaint: or, Night Thoughts on Life, Death and Immortality (I742-6), by the poet and clergyman Edward Young, offers particularly 
clear precedents for topoi that we will encounter in Steele's poems about time. A reading of Young therefore helps us to characterise in some detail the terms of Steele's participation in a national, ecumenical and male-dominated literary culture.

Since the mid-nineteenth century historians have considered Steele almost exclusively as a writer of hymns responding to earlier hymn-writers. ${ }^{\mathrm{I2}}$ More recent studies, however, are also alert to her debts to poets, including Milton, Pope, Swift - and Young. ${ }^{\mathrm{I}}$ Nonetheless, it is fair to say that the few modern studies offering more detailed analyses of what Steele actually wrote continue to focus primarily on the hymns, her Particular Baptist identity or her participation in a multi-generational female poetic coterie that would later include Mary Scott (I75I-I793), the author of a popular paean to female poets, The Female Advocate. ${ }^{\mathrm{I}}$ Rather than placing Steele and her oeuvre exclusively within a particular (nonliterary) genre, a confessional subculture or even a gendered literary lineage, the present article insists that her poems should also be interpreted in terms of their debts to canonical, male-authored poetry. Steele evidently read the major poets of her day; she also responded to them in thoughtful and original ways. This is especially apparent in her poems about time, where Steele's position at the cultural margins - as a nonconformist woman writer - is articulated by sophisticated technical and thematic engagements with poetry written from the centre.

\section{A Christian (Woman) Poet}

Anne Steele was born in I7I 7, in the village of Broughton in Hampshire, to William Steele (I689-I769), a prosperous timber merchant and landowner who was also an active member - eventually pastor - of the local Particular Baptist congregation. ${ }^{15}$ In the latter capacity he developed close ties with a number of important Baptist divines, drawing his family into a Dissenting network that reached well beyond the borders of Hampshire. Growing up within this devout and cultured environment, Anne was notably well educated for a woman of her class and time. Letters and poems exchanged between Anne and her siblings, their relations and their friends attest to wide reading, regular and thoughtful devotional practice and lively literary conversation concerning texts both sacred and worldly. ${ }^{16}$ These various aspects of her education are visible in her literary manuscripts, which consist mostly of fair copies of compositions that were published in print but which also include material that was only ever circulated privately. ${ }^{17}$ Her verse encompasses a remarkable range. In addition to the I 38 hymns written in long, short and common metres Steele also composed poetry in a variety of forms to mark a range of occasions, from births, marriages and especially deaths among her family and friends to major events such as the Lisbon earthquake of I755. Nor is the tone invariably pious, as high-minded verses for her younger relatives in the style of Isaac Watts's Divine Songs [...] for the Use of Children (I7I5) sit alongside lighter, unpublished material that, as we will see, includes witty conversation poems and satires incorporating themes such as courtship and marriage. ${ }^{\mathrm{I} 8}$

By the mid-I750s Steele was attempting to arrange print publication of her verse. Thanks to the efforts of male relatives and friends, in 1760 the hymns were collected and published with a selection of 'occasional poems' as the first volume of Poems on Subjects Chiefly Devotional ... By Theodosia, with a second volume containing further occasional poems and a sequence of metrical psalms. ${ }^{\text {I9 }}$ In addition to attracting compliments from acquaintances, the collection received slight but positive notice in the review press, as well as an enthusiastic verse accolade 'To Theodosia' in The Gentleman's 
Magazine. ${ }^{20}$ Despite her failing health, Steele continued to collect material, and from I775 until her death in I778 she was seeking to publish these 'miscellaneous pieces' including prose meditations - with the original poems in a new, expanded edition. Although she was unsuccessful, her ambition was achieved posthumously by another family friend, the Particular Baptist minister Caleb Evans. The three-volume Bristol edition finally appeared in I780.

The reception of this second edition focused less on the compositions than on a prefatory biography by Evans, thereby establishing the anodyne portrait of Steele that would survive through the Victorian period and into the twentieth century: social retirement, benevolence and piety, and an exemplary Christian death. ${ }^{2 \mathrm{I}}$ Her works suffered accordingly. The nineteenth century saw three issues of a selected edition, but from I893 until I967 only a portion of her hymns remained in print. ${ }^{22}$ This attenuated literary corpus inevitably underscored Steele's posthumous reputation as a modest writer of devotional verse and, above all, as a hymn-writer rather than a poet, a characterisation that bears the marks of late eighteenth- and early nineteenth-century gender norms as well as of the increasingly clear distinction between literary and religious genres in the nineteenth century. Returning to her first entry into print, however, one can discern a different kind of authorial identity from that which took shape after Steele's death.

The title page of Poems on Subjects Chiefly Devotional deftly positions the collection in relation to contemporary literary and devotional culture. The title itself places the emphasis squarely on 'poems', modified only retroactively and at one grammatical remove by 'devotional', thus yoking the religious and the poetic while suggesting that the latter takes precedence. This hybrid identity is further complicated in the pseudonym, since 'Theodosia', 'gift of God', does not specify on whom the gift has been bestowed. Certainly, the pen name acknowledges that Steele's talent and thus its products are not strictly her own but granted by God. She may also, however, be claiming her poems as gifts not just to her individually but to all of mankind.

Modesty, in other words, is only one side of the authorial coin; the other displays considerable ambition, an ambivalence present likewise in the brief epigraph placed below the title: ' — He tunes/ My voice (if tun'd); the nerve that writes, sustains.' ${ }^{23}$ These lines are taken from Young's Night Thoughts. ${ }^{24}$ The immediate and lasting success of that poem means the source and possibly even the lines themselves would have been familiar to likely readers of Steele's book. As such, the quotation functions as a statement of literary - rather than, say, confessional - affiliation. It also reinforces the strategies of self-presentation visible in the pseudonym. A sublime quotation of a divine ventriloquism (God 'tunes' the voice of Young's poet, which Steele in turn appropriates), the epigraph figures poem and author via a variant on the modesty topoi that dominate Steele's own writings. Of these, Aalders 'wonders if Steele's protestations reveal nothing more than a careful modesty', but she fails to recognise that they are largely conventional, relying on well-established lyric and devotional topoi. ${ }^{25}$ The enjambment of Young's lines produces a fleeting alternative reading, namely an intransitive usage ('He tunes') that figures 'the Deity' as above all a God of song, a reading particularly germane to Steele's volumes, dominated as they are by hymns and psalms. ${ }^{26}$ Equally, though, the line-break scores a semiquaver of hesitation that is reinforced by 'if tun'd', which qualifies the confident declarative 'He tunes/ My voice' with a modest hypothetical acknowledging the mysteriousness of poetic grace. The poet, in this formulation, is at once empowered by and dependent on God, and can thus 'sustain' a dual identity as an obedient Christian and a daring poet. By quoting the lines, Steele in her turn makes a similarly hubristic yet humble claim to divine inspiration. 
The authority and polysemy of the epigraph allow Steele to court religious sublimity and yet evade the accusations of enthusiasm that were often aimed at eighteenthcentury religious verse. While the fashion for sensibility and the rise of evangelical Christianity increasingly licensed vivid religious sentiment in literature, poets writing on religious topics still had to contend with equations of claims to divine inspiration with morally noxious affective and/or literary incontinence. ${ }^{27}$ Young in his Night Thoughts registers such views defensively, for example attributing to the poem's infidel adversarius objections that are then rebutted: 'Enthusiastic, This? Then all are Weak,/ But rank Enthusiasts: To this Godlike height,/ Some souls have soar'd; or Martyrs ne'er had bled. ${ }^{28}$

Female poets were still more vulnerable to critiques of enthusiasm. ${ }^{29}$ The fullest review of Poems on Subjects Chiefly Devotional, in the Monthly Review of April I76o, reflects both a distaste for high devotional sentiment and a gendered reading. It introduces Steele as an exception to the pitfalls of devotional poetry and associates her with a minority of successful practitioners exemplified by Watts and his friend and fellow Independent, the poet and novelist Elizabeth Singer Rowe. Yet the reviewer nonetheless notes that Steele is "sometimes borne away, by the ardour of her zeal, to heights far above the ken and compass of cooler reason'. ${ }^{30}$ The somewhat negative, faintly sexualised inflection of 'ardour' and 'zeal' and the contrast between heated, heightened emotions and 'cooler reason' are typical of both anti-enthusiastic rhetoric and contemporary stereotypes regarding female authors. ${ }^{3 \mathrm{I}}$

Steele's choice of epigraph may therefore be read as a pre-emptive defence against the kinds of criticism directed in the period at religious poetry, especially that written by women. In this respect, the quotation from Night Thoughts works not only on the level of the content but as an implicit invocation of the poetic authority that Young represents, an inter-textual strategy that allows Steele to ally herself with masculine, elite literary culture while maintaining a distinctive poetic identity of her own. To read Steele's quotation of Young as a means of countering certain kinds of criticism, then, reconfigures the literary lineage traced for Steele by historians of the hymn, and for example - allows us to recognise her use of inexpressibility and modesty topoi as typical of lyric and the religious sublime rather than solely as a sign of her personal relationship with God or, even, of the soteriological uncertainties of Calvinism. It also helps us to engage with Steele specifically as a woman writer, and to consider the role that literary influence and inter-textuality play in the construction of that gendered identity.

It may admittedly seem counterintuitive to use a male-authored inter-text to elucidate Steele's articulation of a feminine authorial identity. Much of the recent work on eighteenth-century women writers has instead sought to recognise the existence of a developing body of literature by women that provided sources and inspiration for successive generations of female authors, and this kind of approach has indeed produced some of the most valuable scholarship on Steele. ${ }^{32}$ Yet other recent studies of women's writing suggest that segregating it from that of men can blind us to the sophisticated ways in which women authors of this period engage with existing literature, and impoverish rather than enrich our sense of their achievements. ${ }^{33}$ This is the case with Steele, if only because, without exception, the authors she mentions by name in her work - Milton, Watts, Pope, Swift, Thomson, Gray - are men. Her choice of pseudonym, 'Theodosia', identifies the poet quite unambiguously as a woman, as do the two frontispiece images depicting women, which together evoke a distinctively feminine devotional, literary and educational community. ${ }^{34}$ The epigraph from Night Thoughts, however, defines that 
female persona in relation to a masculine poetic tradition. Just as the title page at once expresses enthusiasm and disclaims it, so the author's gender is both advertised and overwritten.

\section{Graveyard Poems and Funeral Bells}

At first glance, Young seems a particularly unlikely model for Steele. An Anglican clergyman whose eclectic religious views seem to have been more or less Arminian, he was not only a paid-up member of the establishment but also part of a metropolitan literary elite whose members were often hostile to the literature of Dissenters, women and other minority groups. ${ }^{35}$ However, research into Dissenting culture increasingly recognises the 'cross-denominational' and 'ecumenical' character of intellectual and cultural exchange in the period. ${ }^{36}$ Young was friends with Pope and Swift, but he was also part of Aaron Hill's literary circle, which included both Watts and Rowe, and although Steele and Young were never personally acquainted, the success of his uninhibitedly pious poem would have had a clear appeal for any writer hoping to publish verse on religious topics, regardless of confessional status. In fact, of all the male poets named by Steele, Young is by far the most prominent in her writings. ${ }^{37}$ Night Thoughts is the source for the valedictory epigraph to the third volume of the I780 edition and is named and quoted in Steele's prose writings, while Young himself is the subject of a manuscript poem. ${ }^{38}$ Less direct allusions and echoes frequently appear. This wider evidence of engagement with a highly successful contemporary poet suggests still more vividly the need for closer literary-critical analysis than Steele's oeuvre has heretofore received. Careful reading of Night Thoughts, furthermore, reveals techniques for representing Christian time that are central also to the rhythms and figures of Steele's poetry.

Young's magnum opus is one of several works that are often identified collectively as 'the graveyard school' of poetry. In a recently published monograph that offers the first extensive consideration of these works and argues for their centrality within contemporary literary culture, Eric Parisot persuasively insists on the usefulness of this admittedly anachronistic classification in identifying a set of themes, strategies and functions shared by poems 'that meditated upon the transience of life, the imminence of death, and (on most occasions) the consolation accorded by a Christian afterlife'. ${ }^{39}$ Parisot explains the popularity of graveyard poetry in terms of the decline of the funeral sermon, on the one hand, and a broad cultural shift from public to private devotion, on the other. As an increasing number of printed catechisms, prayer guides and devotional manuals offered early eighteenth-century readers daily and occasional schedules of 'closet piety' to be performed by individuals in the home, so the lapse of public commemorative practices suggested the need for texts that might enable similarly private modes of mourning. ${ }^{40}$ Graveyard poetry responded to this need. Taking its cue from contemporary theories of poetry's affective efficacy, it combined a heightened emotional register with themes of death and mourning so as to offer scripts for commemorating the dead and contemplating the afterlife.

Graveyard literature is concerned with time not only because it compares the mortal span with the eternal but also because, as Parisot argues, it markets itself at the devotional routines of its readers as a form of reading that might supplement catechisms, prayer books and other forms of devotional literature. Out of a mass of minor and often anonymous verse published in pamphlets, miscellanies and magazines Parisot identifies a small group of poems that he takes as representative of the genre, including Thomas Parnell's $A$ Night-Piece on Death, Robert Blair's The Grave and Thomas Gray's Elegy in a Country 
Churchyard. Among these, Young's Night Thoughts stands out as combining a high degree of poetic accomplishment and didactic force with the fullest (at any rate, the lengthiest) development of the themes of mourning, time and death. These are expressed through verse that is markedly idiosyncratic, presenting a "mixture of witty apothegm and ponderous meditation' via heavily stressed and punctuated blank verse that gives the effect of exclamatory, 'staccato delivery'. ${ }^{\text {I }}$

Such qualities, I would like to suggest, are part of a wider programme related to the virtuous use of time that Sider Jost rightly identifies as Night Thoughts' central didactic message: 'Young's monitory poem is a timekeeper.' ${ }^{42}$ What Sider Jost misses, however, is the close interrelation between the poem's declared function as 'timekeeper' and its representational techniques. Again and again, when time is the theme, the poem draws on the metrical properties of blank verse and the resources of typography to represent the way in which man is quite literally 'out of time' with providence and thereby to urge readers to repentance and devotion, rhythmic effects that are perhaps best understood as a form of aural mimesis. Despite sometimes resulting in rather flat-footed instantiations of Pope's famous dictum that 'Sound must seem an Eccho to the Sense', these nonetheless represent a compelling union between matters of religion and the materials of poetry. ${ }^{43}$

Thus the opening lines of 'Night the Third,' for example, combine a pun on 'punctual' with heavy caesurae that carry moral freight:

Once more I wake; and at the Destin'd

hour;

Punctual as Lovers to the moment sworn,

I keep my Assignation with my Woe. ${ }^{44}$

Just as the Latin punctus forms the root of 'punctual', so in these lines 'pointing' (in the sense of punctuation) is crucial to timekeeping. ${ }^{45}$ The instinct as a reader is to rush the terminal caesura of the first line, to understand 'at the destin'd hour' as post- rather than pre-modifying, and so effectively to read a comma instead of a semicolon. This delivery is balked by the heavy initial stress of the next line, which forces a marked break between lines and rhythms that coincides with the start of a new grammatical clause. Here the haste of lovers, mourners and readers is replicated by an acceleration over the unstressed syllables at the centre of the line, but iambic regularity is reasserted at 'the moment sworn'. Notwithstanding their challenge to the reader, the prosody of the lines as well as their punctuation exactly confirms their grammatical structure and meaning. Thus poetic time contributes to an endorsement of timekeeping and regularity that Night Thoughts as a whole recommends for the devotions of its readers.

Any interruption to the prevailing end-stopping stands out, drawing attention to its semantic implications:

The bell strikes one. We take no note of time

But from its loss. To give it then a tongue

Is wise in man. As if an angel spoke,

I feel the solemn sound. If heard aright,

It is the knell of my departed hours:

[...]

It is the Signal that demands Dispatch. ${ }^{46}$ 
Like the passage that Steele takes for her epigraph, these lines seem carefully constructed to invite comparison between the sound they describe and the sounds they produce. The alliteration and parallel enjambment of 'time' and 'tongue' visually, aurally and rhythmically link the two words to reinforce the conceit by which the bell's clapper is figured as a tongue that speaks time's passing. Coming after mid-line full stops, these enjambments also help to establish the rhythm that dominates succeeding lines, dislocating the blank verse line by a hemistich to produce a disjunction between visual and aural metrical units, which is only resolved when the poet (and by extension the reader) hears the bell 'aright' as 'the knell of my departed hours' and a 'signal' to swift repentance. The sound-patterning thus contributes to the exposition of time's literal, symbolic and exemplary significance.

The passage just quoted is also noteworthy for its invocation of a far older form of chronometry than the watch, one that remained audible in eighteenth-century communities despite the increasing availability of affordable private clocks and watches. In post-Reformation rural England bells still 'punctuated [the people's] most solemn moments' and 'imparted a rhythm to the ordinary functioning of the community'. ${ }^{47}$ The bell, unlike the watch, also represented a characteristically ecclesiastical mode of timekeeping; in the eighteenth century secular bells were rare and church bells remained the preserve of the Established Church ${ }^{48}$ As priest of Welwyn in Hertfordshire, whose parish church boasted a modern bell-tower, Young might therefore have felt peculiarly authorised to appropriate the bell for his poem and to extract a moral from its sound. Unlike the mechanical 'tick' of a watch, furthermore, the bell with its sonorous tongue offered a flattering and well-established analogue for the lyric poem and especially for elegy. ${ }^{49}$ Thus although the eighteenth century arguably saw church bells rendered obsolete as timekeeping devices, as Sherman claims, they evidently remained attractive to poets as richly significant emblems of time and, by their proximity to the churchyard and their tolling for funerals, of death. Among the most important graveyard poems not only Young's Night Thoughts but also, more famously, Gray's Elegy reflects on the sound of a bell.

Given these literary precedents, it is in one sense natural that Steele, a writer of hymns designed for congregational use and an elegist within her family and community, should likewise use the bell to figure death. Equally, however, as a member of a nonconformist congregation, she hears its appeal in ways that distinguish her from Young or Gray. 'On Hearing the Funeral Bell, after Frequent Deaths in the Neighbourhood' and 'A Reflection on Hearing the Bell at the Interment of a Neighbour', first published in the third volume of Poems on Subjects Chiefly Devotional (I780), recall Night Thoughts in their themes, their vocabulary and their exclamatory blank verse, but they also allow us to start distinguishing Steele from the poets who influenced her. In the first of these the sound of the bell warns of death and the swiftness of its approach:

Again, the solemn warning strikes my ear!

The solemn warning that so oft of late

Hath bid my soul be ready! shall the call,

Loud, frequent, pressing, awful, sound in vain ${ }^{50}$

Coming in the wake of three regular iambic lines, the crowded stresses and insistent falling rhythm of 'Loud, frequent, pressing' appear designed to evoke the urgency of the bell's chimes. Similarly Youngian wit appears further on in the contrast between death's 
arrows, 'pointed' by God, and the 'interesting point' of redemption on which the poet urges herself to 'fix'. ${ }^{\text {I }}$ The second poem displays fewer such conceits. Instead, the chimes prompt the poet to imagine her own death as a sentimental funeral scene, which in turn incurs a longing for deliverance that concludes with a hopeful, rapturous vision of death as the time when 'the vital force' of 'strength divine' shall 'tune my quivering lips/ in holy rapture'.$^{2}$ Thus the poet's voice, like the bell that occasions the poem, combines music and devotion.

As in Night Thoughts, the representation of time in these works only makes sense in the double context of religious devotion and poetic practice. Given that church bells 'audibly [...] made manifest the power of the constituted authorities' of church and state, their invocation as stimuli to a Dissenting poet's reflections on Christian time and death seems somewhat dissonant. ${ }^{53}$ The funeral scene imagined in 'A Reflection on Hearing' is, however, faithful to the facts. In Anne's lifetime the Broughton Particular Baptists had no separate burial ground, and she no doubt knew that after her death she would be buried alongside her parents in the Steele family tomb in Broughton parish churchyard. ${ }^{54}$ Thus the time told by the church bells in these poems is to a certain extent the attribute of a devotional 'imagined community' that includes nonconformists such as Steele and her fellow Particular Baptists. ${ }^{55}$ Yet the two poems also register distance from any such community. In neither of them is 'the neighbour' characterised or even lamented, nor is the poet linked sympathetically to the funeral mourners by a recent bereavement such as those experienced by the speaker of Night Thoughts. The second poem, in particular, is noticeably circumspect in its representation of 'that sound', which is never mentioned after the first line. Its reference to the 'sad solemnity of woe/ Which grief or custom waste on senseless clay' might even suggest a critique of Anglican funeral ceremony. ${ }^{56}$

These shifts in emphasis and tone are matched by temporal dislocations, differences in metre that distinguish Steele's bells from that in Night Thoughts. In the poems just described her blank verse is not merely less accomplished but also seems designedly less regular than Young's. In the more successful 'A Reflection on the Close of the Year, Occasioned by Hearing the Bells at Midnight' she deploys an entirely different form. Although the midnight bells of the title and the interrogatory, exclamatory register of the poem recall Night Thoughts, the elegiac metre evokes Gray's Elegy:

Is this a theme of mirth? who can rejoice That Time, important Time so swiftly flies, And scorn Reflection's monitory voice,

The friendly power that wooes us to be wise? ${ }^{57}$

These bells sound both a point in time and the passing of a year, while the pattern of rhythmic suspension and closure afforded by the cross-rhymes counterpoints the poet's pause for reflection with a vivid sense of 'the fleeting now'. ${ }^{8}$ Reflection, the poet's hypostatised interlocutor, urges her to 'seize the precious minutes and make them thine', and the heroic quatrains are indeed perfectly fitted to the poem's dialogic cadence of question and response. ${ }^{59}$ Timeliness is visible also in frequent shifts in units of time (months, days, hours and minutes) and in the logical conjunctions that allow the poet to 'fly' in the space of seven stanzas through a sequence of variations on the tempus fugit motif, arriving in the final lines at 'the feet of sovereign grace' to learn 'how to live and how to die'. 
With its compressed rendering of Night Thoughts' juxtapositions of scale, allegorical abstractions and enthusiastic tone, Steele's 'Reflections' reads almost as a critique of that famously extensive and repetitive poem. Her distance from Young is clearer still in her manuscript verse, however, where the circumscribed readership apparently licenses a wittier and more playful style, as well as a rather different poetic persona bearing the pastoral pseudonym of 'Silviana'. ${ }^{\text {I }}$ Thus, for instance, the bathos latent in graveyard poetry is exploited in playful epitaphs for pets or trees, and in satires that subvert and parody the dirge-like verses of Night Thoughts. ${ }^{62}$ One such composition is a poetic dialogue by Steele, her half-sister Mary Steele Wakeford and their friend Philip Furneaux. Anne as Silviana opens the exchange with these lines:

\author{
The Melancholy passing Bell \\ In doleful accents now may tell \\ The Muse is - No - I must not lie: \\ Immortal Muses cannot die; \\ But ah! the Muse whom Lucius lov'd \\ Is quite elop'd and far removed. ${ }^{63}$
}

The poem starts out in graveyard territory only to 'remove' us from it by way of a parodic marriage plot. In line 3 anacoluthon interrupts the expected narrative and metre with a conversational self-correction, marking the point at which the 'doleful' and predictable 'accents' of graveyard poetry give way to lively wit and unlikely unions. From death knell to wedding bell, the topos is diverted by the muse who has deserted the poet and her admirer, not by dying but in order to marry.

Thus 'melancholy' is transferred from the context of devotion to that of sentimental romance, and the Anglican bell announces the nuptials of a figure from classical mythology. The sequence that follows light-heartedly explores the theme of literary creativity in terms of courtship and marriage, topics that frequently appear in the group's correspondence. Figuring the relationship between poet and muse by turns as a romantic liaison and as celibate dedication, the three contributors play on gendered literary conventions to dramatise wittily the workings of poetic inspiration in ways that lend agency to female authorship.

\title{
III. Time on Paper
}

By way of conclusion, and in order to draw together the moralised, Christian time of 'Theodosia' in Poems on Subjects Chiefly Devotional and the sociable atmosphere evoked in 'The Melancholy passing Bell', I would like to consider the compositional history of 'To My Watch', the poem with which this article began. Rather than being conceived by Steele as Theodosia, it was in fact originally one of a collection of seven manuscript verses composed collaboratively by Anne with her siblings William and Mary. These exist in several variant copies on four separate sheets and are described by Griffin as 'the most complicated piece of manuscript testimony in the Steele canon'. ${ }_{4}$ Whereas most of Anne Steele's poetic manuscripts consist of what appear to be fair copies of finished compositions, these sheets offer rare evidence of her drafting practices, featuring cancellations, corrections and lines transposed within and between individual poems. 
As such, the extraction of 'To My Watch' from the group for publication in the new, 'miscellaneous' volume of Poems on Subjects Chiefly Devotional (I780), and its publication under the name of a single author, conceals its origins as part of a collective endeavour. It also omits a particularly compelling part of the original poems' conceit, since three of the manuscript copies bear the title 'Mottos for a Watch Paper'. ${ }^{65}$ Watch papers are discs of paper that were used in the eighteenth and nineteenth centuries to protect watch faces; commercial, printed versions were often inserted into pocket watches by watchmakers as a form of advertising, but there also seems to have been a late eighteenth-century fashion for commercial and home-made papers bearing emblems, proverbs and mottoes. ${ }^{66}$ The atypically diminutive calligraphy and the partial outline of a circle inscribed on one of the copies suggest that the siblings did indeed intend to insert the poems into a watch or several watches. The collection thus not only sets human time against eternity but also heightens the impact of the conventional juxtaposition by imagining its little devotional sententiae, with their abjurations to 'arise and grasp eternal things', in close proximity to the mortal body. ${ }^{67}$ This is closet piety at its most intimate.

Of the five poems attributable by default to Steele, four cleave to the tetrameter catalectic used through most of 'To My Watch'. The fifth, however, varies the metre more substantially, once again playing with the timings or rhythms of poetry about time.

\author{
Here I view, reflect and sigh \\ How the passing Minutes fly \\ Fleeting Minutes wing'd with haste \\ Here they are and now they're past \\ Forever past, beyond retrieving \\ This gentle admonition leaving \\ Learn wisely future Minutes to employ \\ And look from fleeting Care to lasting Joy. \\ Time a short precarious treasure \\ Cannot yield a during pleasure; \\ Upward let me raise mine eye \\ To a Blest Eternity. \\ There what Joys unmeasur'd dwell \\ Time or thought can never tell. ${ }^{68}$
}

Here the fifth and sixth lines slow down the 'passing Minutes' by adding an extra unstressed syllable at either end, which, like the 'gentle admonition', constitute time's 'leavings' or remains. Next comes a much more stately heroic couplet. As in 'To My Watch', the lengthening of the line occurs as the speaker looks to the future, but the poem then retreats back, via a trochaic octosyllabic couplet, from futurity to the limited present and the time-pressed seven-syllable line. Expanding and contracting, the expectation of 'lasting Joys' is bookended by the partial view of 'Blest Eternity' afforded by the present. The winged minutes are graveyard commonplaces, but the prosody takes Young's techniques one step further by dissenting from the conventions of isosyllabic verse and thereby extending the possibilities of metrical mimesis. Transferred from this group of manuscript poems into the third volume of the Poems on Subjects Chiefly Devotional of I780, the more subtly divergent 'To My Watch' thus represents an attractively (albeit covertly) resonant example of the encounter staged in Steele's time poems between elite male-authored poetry and nonconformist women's writing. 
This article has presented Steele's time poems as a case study of the rhetorical and metrical strategies that I suggest are typical of a body of mid-eighteenth-century poetry which has been addressed by modern scholarship, if at all, with minimal attention to its specifically poetic attributes. Like the scores of poems on religious and moral-didactic themes that appear - often anonymously or under pseudonyms - in the periodicals, anthologies and collections of the mid-century, Anne Steele's oeuvre positively demands a challenge to modern dichotomies of religion/literature and secular/sacred in order to gain purchase on the twenty-first-century historical imagination, either as a historical document of religious belief and practice or as writing that invites literary interpretative strategies. These divisions breached, however, Steele's poetry reveals itself as more artful and more political than has hitherto been recognised, orchestrating time in ways that are representative both of her particular identity and concerns and of wider religiopoetical usages in English verse of the mid-eighteenth century.

\section{NOTES}

I. Anne Steele, 'To My Watch', in Miscellaneous Pieces in Verse and Prose (I780), ed. Julia Griffin, Nonconformist Women Writers, I720-I84O [henceforth NWW], gen. ed. Timothy Whelan, 8 vols (London: Pickering \& Chatto, 20II), vol.II.69. Miscellaneous Pieces is in fact the new, third volume of Steele's Poems on Subjects Chiefly Devotional (I780).

2. OED Online, 'monitor, $n$, II, II .a'.

3. Stuart Sherman, Telling Time: Clocks, Diaries and English Diurnal Form, I660-I785 (Chicago, IL: University of Chicago Press, I996), p.I .

4. Sherman, Telling Time, p.9.

5. Steele, 'To My Watch', l.6, II .

6. Steele, 'To My Watch', 1.8.

7. Jacques Le Goff, 'Au Moyen Age: Temps de l'Eglise et temps du marchand', Annales. Économies, Societés, Civilisations I5:3 (I960), p.4I8. On similar developments in Calvin's Geneva see Max Engammare, On Time, Punctuality, and Discipline in Early Modern Calvinism, trans. Karin Maag (Cambridge: Cambridge University Press, 20Iо).

8. E. P. Thompson, 'Time, Work-Discipline, and Industrial Capitalism', Past and Present 38 (December I967), p.56.

9. Thompson, 'Time, Work-Discipline, and Industrial Capitalism', p.87-8.

IO. For key modern discussions of 'full' versus 'empty' time see: Walter Benjamin on 'Messianic time' versus 'homogeneous, empty time' in 'Theses on the Philosophy of History', in Illuminations, trans. Harry Zorn (London: Pimlico, 1999), p.245-55; the development of these arguments in Benedict Anderson, Imagined Communities: Reflections on the Origin and Spread of Nationalism (London: Verso, I983; rev. edn 2006), p.22-36; and the literary-critical application of the New Testament's kairos and chronos in Frank Kermode, The Sense of an Ending: Studies in the Theory of Fiction (Oxford: Oxford University Press, I967; rev. edn 2000), p.45-5I.

II. Jacob Sider Jost, Prose Immortality, I7II-I8I9 (Charlottesville, VA: University of Virginia Press, 20I5), p.22, 3I . See also Laura Davies, 'Autobiographical Time and the Spiritual "Lives" of Early Methodist Women', Women's Life Writing, I700-1850: Gender, Genre and Authorship (Basingstoke: Palgrave Macmillan, 2012), p.IO3-I6.

I2. For example, Richard Arnold, The English Hymn: Studies in a Genre (New York: Peter Lang, I995), p.373, and Louis F. Benson, The English Hymn: Its Development and Use in Worship (London: Hodder and Stoughton, I9I5), p.2I4.

I3. The most valuable recent scholarship identifies a number of Steele's literary debts: J. R. Watson, The English Hymn: A Critical and Historical Study (Oxford: Clarendon Press, I997), p.I9I; 
Marjorie Reeves, Pursuing the Muses: Female Education and Nonconformist Culture, I70o-I90o (London and Washington: Leicester University Press, I997), p.70; Timothy Whelan, Other British Voices: Women, Poetry, and Religion, I766-I84O (Basingstoke: Palgrave Macmillan, 20I5), p.3-4; Griffin, 'Introduction to Anne Steele', in NWW, vol. I.I8-2I. Two recent monographs discuss Steele's articulation of Baptist devotion: Cynthia Y. Aalders, To Express the Ineffable: The Hymns and Spirituality of Anne Steele (Milton Keynes: Paternoster, 2008); and Priscilla Wong, Anne Steele and Her Spiritual Vision: Seeing God in the Peaks, Valleys and Plateaus of Life (Grand Rapids, MI: Reformation Heritage Books, 20I2).

I4. The Female Advocate; A Poem. Occasioned by Reading Mr. Dunscombe's Feminead (London, I774); see NWW, vol. IV.28-45.

I5. This biographical summary draws chiefly on J. R. Broome, A Bruised Reed: The Life and Times of Anne Steele (Harpenden: Gospel Standard Trust, 2007).

I6. For example, correspondence of Anne and William Steele, MS D/STE 3/8, Steele Papers, Angus Library and Archive, Regent's Park College, Oxford [henceforth Angus]; correspondence of Anne Steele and Mary Steele Wakeford, Angus MS D/STE 3/IO; the commonplace book of William Steele, Angus MS D/STE 4/2; and 'Ye happy kind Mortals, ye Married folks, say', conversation poem by Anne Steele, Mary Steele Wakeford and Philip Furneaux, Angus MS D/STE 3/3/7, nos I-4. Thanks are due to the Angus Library and Archive for granting me access to the Steele papers, and especially to Regent's Park College librarian Revd Emma Walsh for her generous assistance.

I7. The collection is described in Griffin, 'Introduction to the Poems of Anne Steele', p.I5.

I8. Watts is an important influence on the entirety of Steele's oeuvre. His Hymns and Spiritual Songs (I7O7) were often sung by the Broughton congregation, and Steele's writings evidence a close familiarity with it (Broome, A Bruised Reed, p.87, II6).

I9. Anne Steele, Poems on Subjects Chiefly Devotional. In Two Volumns. By Theodosia [sic] (London, I760).

20. R. Pearsall to Joseph Wakeford [prior to I760], transcribed by Anne Steele, Angus MS D/STE 3/6/4. 'Art. I9', The Critical Review; or, Annals of Literature 9 (February I760), p.I54. G., 'Poems, on Subjects Chiefly Devotional', Monthly Review; or, Literary Journal 22 (April I760), p.32I-4. W. O., 'To THEODOSIA, Author of Two Volumns of Poems Lately Published', The Gentleman's Magazine: and Historical Chronicle 3I (February I76I), p.89.

2I. Caleb Evans, 'Advertisement', in Anne Steele, Poems on Subjects Chiefly Devotional. In Two Volumes. A New Edition. To Which Is Added, a Third Volume, Consisting of Miscellaneous Pieces, 3 vols, ed. Caleb Evans (Bristol, I780), vol.III.iii-xi. Reviews of the second edition include 'Art. III', Monthly Review; or, Literary Journal 66 (May I782), p.337-9, and 'An Account of the Late Mrs. Anne Steele, Author of a Collection of Poems, in Three Volumes', Universal Magazine of Knowledge and Pleasure 70 (June I782), p.58-9.

22. Anne Steele, Hymns, Psalms and Poems. With a Memoir by John Sheppard (London, I863; repr., London: Charles Gordelier, I882).

23. Steele, Poems on Subjects Chiefly Devotional. In Two Volumns. By Theodosia (I760), title page.

24. Edward Young, Night Thoughts, ed. Stephen Cornford (Cambridge: Cambridge University Press, I989) [henceforth NT], Night IV, l.4OI-2.

25. Aalders, To Express the Ineffable, p.76.

26. 'Praise I a distant Deity? He tunes / [...]'.

27. There is a now a substantial body of scholarship on 'poetic enthusiasm' in the long eighteenth century. Jon Mee notes the continuing 'instability' of the 'discourse of enthusiasm' in the mid- to late eighteenth century: Enthusiasm and Regulation Poetics and the Policing of Culture in the Romantic Period (Oxford: Oxford University Press, 2003), p.2-4.

28. Young, NT, Night VI, l.603-5.

29. See Clement Hawes, Mania and Literary Style: The Rhetoric of Enthusiasm from the Ranters to Christopher Smart (Cambridge: Cambridge University Press, I996), p.I79. 
30. G., 'Poems, on Subjects Cheifly Devotional', p.322.

3I. See Helen Boyle, Romanticism and Methodism: The Problem of Religious Enthusiasm (Abingdon: Routledge, 20I6), p.2-5.

32. Notably by Reeves and Whelan. From a social/religious history perspective, see also Karen E. Smith, 'Beyond Public and Private Sphere: Another Look at Women in Baptist History and Historiography', Baptist Quarterly 34 (I99I-2), p.79-87.

33. E.g. Paula R. Backscheider, Eighteenth-Century Women Poets and Their Poetry: Inventing Agency, Inventing Genre (Baltimore, MD: Johns Hopkins University Press, 2005), p.32; Jane Spencer, Literary Relations: Kinship and the Canon, I660-I830 (Oxford: Oxford University Press, 2008); and Jennie Batchelor, 'Influence, Intertextuality, Agency: Eighteenth-Century Women Writers and the Politics of Remembering', Women's Writing 20:I (2013), p.3.

34. Both frontispieces represent pairs of women, one depicted as a bearer of devotional illumination and the other as a student. See Watson, The English Hymn, p.I9I, and Nancy Jiwon Cho, 'Widening Perspectives on Theodosia's Legacy as the "Mother" of British Hymn-Writing: The Divergent Reponses of Three Contemporary Nonconformist Women Poets to Anne Steele's Exemplary Authorial Identity', Journal of English Language and Literature 63:2 (20I7), p.244-6.

35. The most complete biography is Walter Thomas, Le poète Edward Young (I683-I765): étude sur sa vie et ses ceuvres (Paris: Hachette, I90I).

36. Tessa Whitehouse, The Textual Culture of English Protestant Dissent I720-I80o (Oxford: Oxford University Press, 20I6), p.3.

37. Griffin comments that Steele 'quotes and mentions' Night Thoughts 'more than any other work'. 'Introduction to Anne Steele', p.I5.

38. Anne Steele, 'Comfort under the Painful Sense of Frailty, in the Unchangeable Goodness of God', NWW, vol. II.24I, and 'On the Death of Dr. Young', Angus MS D/STE 3/3/2, p.25.

39. Eric Parisot, Graveyard Poetry: Religion, Aesthetics and the Mid-Eighteenth-Century Poetic Condition (Farnham: Ashgate, 2013), p.I .

40. Parisot, Graveyard Poetry, p.IO-I8; see also Evert Jan Van Leeuwen, 'Funeral Sermons and Graveyard Poetry: The Ecstasy of Death and Bodily Resurrection', Journal for Eighteenth-Century Studies 32:3 (2009), p.353-7I.

4I. Blanford Parker, The Triumph of Augustan Poetics: English Literary Culture from Butler to Johnson (Cambridge: Cambridge University Press, I998), p.227. John Barrell and Harriet Guest, 'On the Use of Contradiction: Economics and Morality in the Eighteenth-Century Long Poem', in Felicity Nussbaum and Laura Brown (eds), The New Eighteenth Century: Theory, Politics, English Literature (New York: Methuen, I987), p.I39.

42. Sider Jost, Prose Immortality, p.47.

43. Alexander Pope, 'An Essay on Criticism', in The Poems of Alexander Pope, ed. John Butt (New Haven, CT: Yale University Press, I963), l.365.

44. Young, NT, Night III, 1.3-5. The accidentals in this passage remain consistent throughout the early quarto editions printed for Robert Dodsley.

45. For eighteenth-century usage see 'Punctual, n.5', in OED Online; http://www.oed.com [accessed June 20I6].

46. NT, Night I, l.54-6o.

47. Alain Corbin, Village Bells: Sound and Meaning in the I9th-Century French Countryside, trans. Martin Thom (New York: Columbia University Press, I998), p.xi. On the continued albeit restricted use of parochial bells in post-Reformation England see Percival Price, Bells and Man (Oxford: Oxford University Press, I983), p.I30-32.

48. Dissenting churches were not granted the right to summon their congregations by bell-ringing until the nineteenth century (Price, Bells and Man, p.I32).

49. Sherman on eighteenth-century transliteration of the sound of watches, Telling Time, p.5-8. 
50. NWW, vol. II.I4-I6 (l.I-4).

5I. NWW, vol. II.I4-I6 (l.I9, 45-6).

52. NWW, vol. II.I4-I6 (l.35, 37-8).

53. Corbin, Village Bells, p.I58.

54. See Broome, A Bruised Reed, p.214-22.

55. See Anderson, Imagined Communities. In this respect the 'bell' poems may usefully be read alongside the poems Steele composed for various days of public repentance, mourning and celebration instituted by George II during the Seven Years War.

56. NWW, vol. II.4O-4I (l.I, I2-I3).

57. NWW, vol. II.62-3 (l.I -4).

58. NWW, vol. II.62-3 (l.24).

59. NWW, vol. II.62-3 (l.Io).

6o. NWW, vol. II.62-3 (l.26, 22, 28$)$.

6I. Griffin, 'Introduction to Anne Steele', p.I5.

62. Angus MS D/STE 3/3/I, includes 'On the Death of an Old Apple Tree' (p.I7), 'Epitaph on a Favourite Dog' (p.70) and 'Epitaph on a Cock' (p.84).

63. 'The Melancholy Passing Bell', Angus MS D/STE 3/3/I, p.2O, l.I-6.

64. Angus MS D/STE 3/3/6, fols I6, I6(a), I6(b), I6(c). Griffin, NWW, vol.II.357.

65. Namely I6(a), (b) and (c), the three copies that include versions of all the poems.

66. On watch papers see: Peacay, 'Watch-Paper Prints', BibliOdyssey (blog), 26 May 2009, http://bibliodyssey.blogspot.co.uk/2009/05/watch-paper-prints.html [accessed March 2015]; Lew Jaffee 'Watch Papers', Confessions of a Bookplate Junkie (blog), 6 February 20Iо, http://bookplatejunkie.blogspot.co.uk/2OIO/O2/watch-papers.html [accessed March 20I5]. The British Museum online image archive includes a number of commercial watch papers (http://bmimages.com).

67. 'Time a short precarious treasure', Angus MS D/STE 3/3/6, fol.I6(c), vI , l.3. I follow Griffin in taking $\mathrm{I} 6(\mathrm{c})$ as the copy text but not her practice of interpolating conventional punctuation.

68. 'Here I view reflect and sigh', Angus MS D/STE 3/3/6, fol.I6(c) rI.

KATARINA STENKE is a lecturer in eighteenth-century British literature at the University of Greenwich. She completed her MPhil and PhD (2013) in eighteenth-century British literature at the University of Cambridge. Current research interests include the motif of imposture in Joseph Addison and the representation of time and death in eighteenth-century women's writing. 